\title{
Mites associated with Citrus latifolia (Rutaceae) from an orchard at Artur Nogueira municipality, São Paulo state, Brazil
}

\author{
Jeferson L. C. Mineiro ${ }^{ \pm=}$, Adalton Raga
}

\begin{abstract}
APTA, Instituto Biológico, Centro Avançado de Pesquisa em Proteção de Plantas e Saúde Animal, 13101-680, Campinas, São Paulo, Brazil.

奉=Corresponding author: jefmin@hotmail.com
\end{abstract}

Edited by: Peterson R. Demite

Received: January 27, 2020. Accepted: June 09, 2020. Published: August 04, 2020.

\begin{abstract}
Citrus latifolia Tanaka (Rutaceae) is a perennial and spinescent citrus tree. Knowledge of the mite fauna on this plant in São Paulo state is limited. The aim of this work was to survey the mite species from a C. latifolia orchard in Artur Nogueira municipality, central-eastern region of São Paulo state. Leaf samples were collected every two weeks from November 2011 to April 2012 for examination under a stereomicroscope. Mites found were mounted on microscopic slides in Hoyer's medium. In total, 147 mites representing 21 species of 11 families were found. Panonychus citri (McGregor, 1916) (Tetranychidae) was the dominant phytophagous species, accounting for about $20 \%$ of all mites. The predatory mite family Phytoseiidae was the most diverse, comprising nine species. Brevipalpus yothersi Baker, 1949 and $P$. citri are reported for the first time in C. latifolia in Brazil.
\end{abstract}

Keywords: Acari, Euseius concordis, Iphiseiodes zuluagai, Panonychus citri, Taiti lime.

Citrus plants are attacked by several species of pest mites, among them Phyllocoptruta oleivora (Ashmead, 1879) (Eriophyidae), Eutetranychus banksi (McGregor, 1914), Panonychus citri (McGregor, 1916), Tetranychus mexicanus (McGregor, 1950) (Tetranychidae), Brevipalpus yothersi Baker, 1949 and Brevipalpus papayensis Baker, 1949 (Tenuipalpidae) (Smith \& Peña 2002; Mineiro et al. 2018). Predatory mites of the family Phytoseiidae are important natural enemies of pest mites in citrus agroecosystems, especially Iphiseiodes zuluagai Denmark \& Muma, 1972, Euseius citrifolius Denmark \& Muma, 1970 and Euseius concordis (Chant, 1959) (Gravena et al. 1994; Sato et al. 1994; Raga et al. 1996; Reis 2000; Sato 2005).

Citrus latifolia Tanaka (Rutaceae), popularly known as Tahiti lime in Brazil, is a perennial, spinescent fruit tree that reaches up to $6 \mathrm{~m}$ in height. The fruits are consumed in the form of juice or otherwise industrialized (Lorenzi et al. 2006). Knowledge of mite fauna on plants of this species in São Paulo state is limited. The objective of this study was to evaluate the mite diversity in commercial orchards of Tahiti lime.

Samplings were carried out in an orchard located in Fazendinha

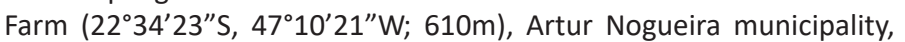
in the central-eastern region of São Paulo state, Brazil. Ten leaves of this plant were collected biweekly from the middle third of 10 plants from November 2011 to April 2012. They were placed in paper bags, which in turn were placed in a cooled isopropylene box to decrease mite activity and for transport to the laboratory.

The extraction of the mites was carried out in the laboratory by submerging the sampled leaves for 5 minutes in a solution of water + detergent. The solution was vigorously agitated to dislodge the mites from the samples. The mites were sieved $(0.038 \mathrm{~mm}$ mesh) and mounted on microscope slides in Hoyer's medium. Voucher specimens were deposited in "Geraldo Calcagnolo" Mite Reference Collection, Instituto Biológico (ICMBio authorization 35919-1).

A total of 147 mites representing 21 species of 11 families were found (Tab. 1). Phytophagous mites (Eriophyidae, Tenuipalpidae and Tetranychidae) represented approximately $37 \%$ of the mites found. Panonychus citri was the dominant species, representing about $20 \%$ of all mites collected (Tab. 1).
Predatory mites (Cunaxidae, Ascidae, Blattisociidae and Phytoseiidae) represented approximately $46 \%$ of the mites found, with a predominance of Phytoseiidae, the most diverse (nine species) and abundant (64 specimens) family. Iphiseiodes zuluagai and E. concordis were the dominant phytoseiids, representing 24 and $7 \%$ of the mites of this family, respectively (Tab. 1).

Several phytoseiid species recorded in this study have already been reported on citrus in São Paulo state, such as Amblyseius chiapensis De Leon, 1961, Amblyseius acalyphus Denmark \& Muma, 1973, E. citrifolius, I. zuluagai and Metaseiulus (Metaseiulus) camelliae (Chant \& Yoshida-Shaul, 1983) (Sato et al. 1994). The predominance of phytoseiids on citrus have also been reported in this state in previous studies (Sato et al. 1994; Raga et al. 1996; Reis 2000).

Tahiti lime has been reported to be severely attacked by phytophagous mites e. g. Eriophyidae, Tenuipalpidae and Tetranychidae in Brazil (Silva et al. 2017). In the present work, we found two specimens of $B$. yothersi (Tenuipalpidae), which has been mentioned as an important vector of citrus leprosis virus (Nunes et al. 2018). However, leprosis symptom was not observed here. Phyllocoptruta oleivora, T. mexicanus and Brevipalpus phoenicis (Geijskes, 1939) sensu lato are also common plant-feeding mites on leaves, fruits and branches of Tahiti lime in Venezuela (Quiros-Gonzalez 2000), but these species above were rare or absent in the present work.

None of the leaf samples collected in this study showed significant damage caused by the phytophagous mites. Some phytophagous species found here, such as $P$. citri and Tetranychus sp., have been reported to reach relatively high abundance on Tahiti lime in Florida (Childers \& Abou-Setta 1999), but the population number of these mites in our study was always low. The absence of significant damage indicated that the phytophagous mites were in ecological equilibrium, probably at least partly due to the action of natural enemies.

Although the Tahiti lemon crop is of great economic importance for Brazilian exportations, the mite diversity is poorly known. In the present study, $B$. yothersi and $P$. citri are reported for the first time on C. latifolia in Brazil. 
Table 1. Mite species from leaves of Citrus latifolia in Artur Nogueira municipality, São Paulo state, from November 2011 to April 2012.

\begin{tabular}{|c|c|c|}
\hline \multicolumn{2}{|c|}{ Taxa (predominant feeding habit) ${ }^{1}$} & \multirow[t]{2}{*}{ Abundance } \\
\hline & rombidiformes, Prostigmata & \\
\hline Cunaxidae (Pr) & Armascirus sp. & 1 \\
\hline Eupodidae (Un) & Eupodes sp. & 1 \\
\hline Eriophyidae (Ph) & Phyllocoptruta oleivora & 1 \\
\hline Tenuipalpidae (Ph) & Brevipalpus yothersi & 2 \\
\hline \multirow[t]{3}{*}{ Tetranychidae (Ph) } & Eutetranychus sp. & 1 \\
\hline & Panonychus citri & 30 \\
\hline & Tetranychus sp. & 21 \\
\hline Tydeidae (Ph) & Lorryia formosa & 19 \\
\hline \multicolumn{3}{|c|}{ Sarcoptiformes, Oribatida } \\
\hline Oppiidae (Ot) & Aeroppia sp. & 2 \\
\hline Acaridae (Ot) & Tyrophagus putrescentiae & 2 \\
\hline \multicolumn{3}{|c|}{ Mesostigmata } \\
\hline Ascidae (Pr) & Asca sp. & 2 \\
\hline Blattisociidae (Pr) & Lasioseius sp. & 1 \\
\hline \multirow[t]{9}{*}{ Phytoseiidae (Pr) } & Amblyseius chiapensis & 4 \\
\hline & Amblyseius herbicolus & 1 \\
\hline & Amblyseius sp. & 3 \\
\hline & Euseius citrifolius & 3 \\
\hline & Euseius concordis & 11 \\
\hline & Euseius mesembrinus & 4 \\
\hline & Iphiseiodes saopaulus & 2 \\
\hline & Iphiseiodes zuluagai & 35 \\
\hline & Proprioseiopsis neotropicus & 1 \\
\hline
\end{tabular}

(1) Pr: predator; Ph: phytophagous; Ot: other; Un: unknown

\section{Acknowledgements}

To Dalva Gabriel, Instituto Biológico and Dr. Gilberto Moraes, USP/ ESALQ for critically reviewing the manuscript.

\section{Authors' Contributions}

JLdeCM and AR designed the study, discussed the results, and wrote the manuscript. AR conducted the field activities. JLdeCM classified and identified the specimens.

\section{References}

Childers, C. C.; Abou-Setta, M. M. (1999) Yield reduction in 'Tahiti' lime from Panonychus citri feeding injury following different pesticide treatment regimes and impact on the associated predacious mites. Experimental and Applied Acarology, 23: 771-783. doi: 10.1023/A:1006285209533

Gravena, S.; Benetoli, I.; Moreira, P. H. R.; Yamamoto, P. T. (1994) Euseius citrifolius Denmark \& Muma predation on citrus leprosis mite Brevipalpus phoenicis (Geijskes) (Acari: Phytoseiidae: Tenuipalpidae). Anais da Sociedade Entomológica do Brasil, 23(2): 209-218.

Lorenzi, H.; Bacher, L.; Lacerda, M.; Sartori, S. (2006) Frutas brasileiras e exóticas cultivadas (de consumo in natura). São Paulo: Instituto Plantarum de Estudos da Flora.

Matioli, A. L.; Ueckermann, E. A.; Oliveira, C. A. L. (2002) Some stigmaeid and eupalopsellid mites from citrus orchards in Brazil
(Acari: Stigmaeidae and Eupalopsellidae). International Journal of Acarology, 28(2): 99-120. doi: 10.1080/01647950208684287

Mineiro, J. L. C.; Sato, M. E.; Ochoa, R.; Beard, J.; Bauchan, G. (2018) Revisão taxonômica do ácaro da leprose dos citros e sua distribuição no Brasil. Citrus Research and Technology, 39, e1036. doi: 10.4322/ crt.17147

Nunes, M. A.; Mineiro, J. L. C.; Rogerio, L. A.; Ferreira, L. M.; Tassi, A.; Novelli, V. M.; Kitajima, E. W.; Freitas-Astúa, J. (2018) First report of Brevipalpus papayensis Baker (Acari: Tenuipalpidae) as vector of Coffee ringspot virus and Citrus leprosis virus C. Plant Disease, 102(5): 1046. doi: 10.1094/PDIS-07-17-1000-PDN

Quiros-Gonzalez, M. (2000) Phytophagous mite populations on Tahiti lime, Citrus latifolia, under induced drought conditions. Experimental and Applied Acarology, 24: 897-904. doi: 10.1023/a:1010744009094

Raga, A.; Sato, M. E.; Cerávolo, L. C.; Rossi, A. C. (1996) Distribuição de ácaros predadores (Phytoseiidae) em laranjeira (Citrus sinensis L. Osbeck). Ecossistema, 21: 23-25.

Reis, P. R. (2000) Ácaros da família Phytoseiidae associados aos citros no município de Lavras, sul de Minas Gerais. Anais da Sociedade Entomológica do Brasil, 29(1): 95-104.

Sato, M. E. (2005) Perspectivas do uso de ácaros predadores no controle biológico de ácaros-praga na citricultura. Laranja, 26(2): 291-306.

Sato, M. E.; Raga, A.; Cerávolo, L. C.; Rossi, A. C.; Potenza, M. R. (1994) Ácaros predadores em pomar cítrico de Presidente Prudente, Estado de São Paulo. Anais da Sociedade Entomológica do Brasil, 23(3): 435-441.

Silva, R. R.; Teodoro, A. V.; Martins, C. R.; Carvalho, H. W. L.; Silva, S. S.; Farias, A.P.; Guzzo, E. C. (2017) Seasonal variation of pest mite populations in relation to citrus scion cultivars in northeastern Brazil. Acta Agronómica, 66(2): 290-295. doi: 10.15446/acag. v66n2.55041

Smith, D.; Peña, J. E. (2002) Tropical citrus pest. In: Peña, J. E.; Sharp, J. L.; Wysoki, M. (Eds.), Tropical Fruit Pests and Pollinators - Biology, Economic Importance and Control, pp. 57-101. Wallingford: CABI Publishing. 